\title{
Effect Of Macroeconomic Variables On Stock Market Returns For Four Emerging Economies: Brazil, Russia, India, And China
}

\author{
Robert D. Gay, Jr., (Email: rgay@nova.edu), Nova Southeastern University
}

\begin{abstract}
The relationship between share prices and macroeconomic variables is well documented for the United States and other major economies. However, what is the relationship between share prices and economic activity in emerging economies? The goal of this study is to investigate the timeseries relationship between stock market index prices and the macroeconomic variables of exchange rate and oil price for Brazil, Russia, India, and China (BRIC) using the Box-Jenkins ARIMA model. Although no significant relationship was found between respective exchange rate and oil price on the stock market index prices of either BRIC country, this may be due to the influence other domestic and international macroeconomic factors on stock market returns, warranting further research. Also, there was no significant relationship found between present and past stock market returns, suggesting the markets of Brazil, Russia, India, and China exhibit the weak-form of market efficiency.
\end{abstract}

Keywords: macroeconomics, exchange rates, oil prices, stock prices, Brazil, Russia, China, and time-series

\section{INTRODUCTION}

¿ n recent The Economist articles concerning the shortfall of buyers of developed countries' assets, it was mentioned this shortfall could be made up by adding investors from emerging economies. However, for this to happen, continued growth in the emerging financial markets (EFMs) needs to continue their respective expansion, pushed by external investors. Wilson and Purushothaman (2003) identified four emerging markets (Brazil, Russia, India, and China or BRICs) which together could be larger in U.S. dollar terms than the G6 within the next forty years. The BRICs are the four biggest emerging economies combined they account for twofifths of the total Gross Domestic Product (GDP) of all emerging economies. Recently revised GDP statistics by the World Bank based on purchasing-power parity (PPP) showed GDP for China in 2005 was $\$ 5.3$ trillion, compared with $\$ 2.2$ trillion using market exchange rates (which can understate GDP figures) and $\$ 8.9$ trillion using previous PPP estimates in contrast India's GDP has also been slashed by almost 40\%. With Brazil's GDP also down a bit, the share of emerging economies in world output (including Asia's newly industrializing economies) has been cut to $46 \%$ in 2005, compared with over 50\% using previous numbers. However, GDP in PPP terms, all four still rank among the world's top ten economies, with China and Brazil ranking among the top ten when market exchange rates are taken into account. Also, in terms of PPP, Brazil and Russia both produce more than India, which is expected to grow at the rate of five percent per year for the next thirty years. Tarzi (2000 and 2005) researched the flow of both foreign portfolio equity investments (FPEI) and foreign direct investment (FDI) to emerging markets. Between 1986 and 1995 stock market capitalization in emerging countries grew ten-fold from $\$ 171$ billion to 1.9 trillion and market share held in capitalization increased from 4 percent to 11 percent, mostly to the nine major emerging markets including Brazil, India, and Hong Kong (now a province of China). In the 1990s FDI in developing countries as a ratio of GDP increased from 7 to 21 percent. Most of the increase in FDI went to developing countries like Brazil, China, and India. Russia, since the dissolution of the Soviet Union and the financial crisis of 
1997, has achieved more price and currency stabilization, orderly elections, and seen its inflation rate drop from $215 \%$ in 1994 to $8.3 \%$ in 1998, making it an attractive target for diversifying asset holdings.

Given the background previously provided leads to the questions: Can time-series analysis of stock market indices be explained significantly by corresponding macroeconomic variables of exchange rate and oil prices? If so, then how significant are the relationships and how can they be described? And do the respective stock markets of Brazil, Russia, India, and China exhibit the weak, semi-strong, or strong form of market efficiency?

To answer these related questions this study will examine the monthly averages of respective stock market indices, foreign exchange rates, and oil price between 1999 and 2006. The Box-Jenkins Autoregressive Integrated Moving Average (ARIMA) time-series process will be used to determine the relationship between the dependent variable (stock market index) to the independent variables (exchange rate and oil price).

Other than serving as a primer for analyzing the time-series correlation between the BRIC stock market indices and foreign exchange rates and oil prices, this study will provide an assessment of the market efficiency of each country, allowing investors to make an assessment of market risks for each respective BRIC country involving past market prices and macroeconomic variables. The remainder of this paper is set out as follows. The next section provides a brief overview of the literature of similar studies conducted on stock market prices and macroeconomic variables for other EMFs. Section 3 outlines the methodology for the ARIMA model used for the individual BRIC companies. Sections 4 and 5 provide an analysis of results and conclusion of the study, respectively.

\section{LITERATURE REVIEW}

Research into the relationship between stock market returns and multiple macroeconomic variables for EFMs has been limited. These studies include, but are not limited to, Goodhart, Mahadeva, and Spicer's (2003) research into the effect of monetary policy changes on asset prices in the foreign exchange and equity markets, which attributed failure to find monetary policy effectiveness during a crisis to policy failure and the risk premia in the financial markets of Brazil and Korea. Basher and Sadorsky's (2006) exploration of the impact of oil price changes on the stock market returns of 21 emerging economies found strong evidence of the effect of oil prices being positive and statistically significant at the $10 \%$ level to stock market returns for most of the countries studied.

One of the earliest studies to provide an assessment of stock market behavior and various multiple macroeconomic variables for an EMF was conducted by Kwon, Shin, and Bacon (1997) for the South Korean stock market between January 1980 and December 1992. The independent variables consisted of a production index, inflation and expected inflation, risk premium, term structure, dividend yield, trade balance, foreign exchange rate, oil price, and money supply that were time-series regressed on monthly returns of the value-weighted Korea Composite Stock Price Index (KOSPI). Their results showed that the Korean stock market was more sensitive to real economic and international trading activities, measured in terms of foreign exchange rates, trade balance, the money supply, and the production index, than that of the U.S. and Japanese stock indexes. These markets that have been shown to be sensitive to inflationary variables such as the change in unexpected inflation, expected inflation, the risk premium, and term structure [Chen, Roll, \& Ross (1986), Burmeister \& Wall (1986), Hamao (1988), and Chen (1991)].

The most comprehensive research into the linkage of stock prices and macroeconomic factors was conducted by Muradoglu, Taskin, and Bigan (2000), Diacogiannis, Tsiritakis, and Manolas (2001), and Wongbangpo and Sharma (2002), and Mukhopadhyay and Sarkar (2003). Muradoglu et al. investigated possible causality between 19 emerging market returns and exchange rates, interest rates, inflation, and industrial production from 1976 to 1997. Their results revealed that the relationship between stock returns and macroeconomic variables were mainly due to the relative size of the respective stock market and their integration with world markets. In their study of the Greek stock market between 1980 and 1992 and its relationship to 18 macroeconomic variables, Diacogiannis et al. found significant high loadings between stock returns and 13 of the 19 macroeconomic variables for both periods, 1980-1986 and 1986-1992. Wongbangpo and Sharma explored the relationship between the stock 
returns for the ASEAN-5 countries of Indonesia, Malaysia, the Philippines, Singapore, and Thailand and five macroeconomic variables. By observing both short and long run relationships between respective stock indexes and the macroeconomic variables of gross national product (GNP), the consumer price index (CPI), the money supply, the interest rate, and exchange rate they found that in the long-run all five stock price indexes were positively related to growth in output and negatively to the aggregate price level. But a negative long-run relationship between stock prices and interest rates was noted for the Philippines, Singapore, and Thailand, and was found to be positive for Indonesia and Malaysia. In the end, causality tests detected an overall relationship between macroeconomic variables and stock prices for all five ASEAN equity markets. Lastly, Mukhopadhyay and Sarkar conducted a systematic analysis of the Indian stock market returns prior to and after market liberalization and the influence of macroeconomic factors on returns. Specifically for the post-liberalization period (since 1995), real economic activity, inflation, money supply growth, FDI, and the NASDAQ-index were significant in explaining variations in Indian stock return. Nominal exchange rate, while significant during the pre-liberalization period (1989-1995), was found to not be significant after liberalization.

\section{METHODOLOGY}

The empirical question is whether macroeconomic factors of EMFs such as the foreign exchange rate and oil price significantly explain stock market returns. The Box-Jenkins ARIMA model used to describe the relationship will use the moving-averages at the one-month MA(1), three-month MA(3), six-month MA(6), and twelve-month MA(12) for the lagged dependent of stock market price and the two intervening variables of exchange rate and oil price.

Available monthly data for stock market price index, exchange rate, and oil price between 1999:03 to 2006:06 for Brazil, Russia, India, and China from the Organization for Economic Cooperation and Development (OECD) will be used in this study, which will provide 90 observations per variable for each BRIC for a total of 1,080 observations.

This paper hypothesizes a positive relation between the exchange rate and the stock market index. Among others, Solnik (1987), Soenen and Hennigar (1988), Ma and Kao (1990), and Mukherjee and Naka (1995) indicate that both the levels of and changes in exchange rate levels affect the performance of a country's stock market. Ma and Kao (1990) and Mukherjee and Naka (1995) suggest that for an export-orientated economy a currency depreciation will have a favorable impact on the domestic stock market. They found that as ASEAN currencies depreciated against the U.S. dollar their respective exported products became comparatively cheaper on the world market, thus increasing aggregate demand for them. If demand is elastic export volume would increase, causing increased cash flows and profits and generally increase the stock price of domestic firms (or vice versa for currency appreciation against the U.S. dollar or USD). For the purpose of this study the average monthly foreign exchange per USD will be used in the model.

The relationship between crude oil prices and stock prices is hypothesized to be negative in nature. As energy prices rise, production and input costs will generally increase, decreasing firm gross profits and cash flows. This perceived risk will further erode investor confidence and increase their search for alternative investments or cost-cutting activities, through lowered production. Toloui (2007) researched the effect of oil prices and the cash reserves of oil exporters and found a $\$ 10$ increase in the price of crude oil brought by exporters increased their revenue between $\$ 90$ billion to $\$ 100$ billion annually, with at least $40 \%$ of the increase in cash reserves being invested in bank deposits and short-term securities. This study will be using the average monthly North Sea Brent crude oil price as the other time-series independent variable.

The Box-Jenkins time-series modeling process requires discrete time-series data which is equally spaced over time with no missing values and stationary in the mean, variance, and autocovariance. The presence of nonstationarity was confirmed using the Dickey-Fuller test, with subsequent transformations to stationarity using first-order differencing. First-order differencing removed any stochastic trend, with the variable series exhibiting a constant mean. 


\section{ANALYSIS AND PRESENTATION OF FINDINGS}

In conducting the Dickey-Fuller test on the original time-series datasets it was found that the null hypothesis could not be rejected for the dependent (stock price) and both independent variables (exchange rate and oil price) for Brazil, China, and India, with the same null hypothesis not being rejected for both stock and oil price for Russia at the one and five percent confidence level. By taking the first-order differencing for all three variables the null hypothesis for nonstationarity was rejected for all variables across all four countries at the same confidence levels, lending continuity in the modeling process.

The results of the Box-Jenkins ARIMA models for each country with MA(1), MA(3), MA(6), and MA(12) intervening variables of exchange rate and oil price are detailed in Tables 1-4. As mentioned earlier, the first-order differencing of each variable was used to ensure both continuity and stationarity. Both the Durbin-Watson and the modified Ljung-Box Q-statistic were used to test for autocorrelation. More emphasis should be placed on the modified Q-statistic, as it does not inflate the autocorrelation under conditions of short series or short lag times as the Portmanteau statistic.

The Durbin-Watson statistic showed no presence of autocorrelation for Brazil, Russia, and China at the one and five percent significance levels. With India the Durbin-Watson statistic revealed negative autocorrelation after the MA(1) level. For the BRICs the significance value of the Ljung-Box modified Q-statistic of each country was not less than 0.05 for each model, except for India at MA(3) and MA(12). Further examination on the India dataset using the Durbin-Watson statistic showed no autocorrelation at the MA(1) level for both significance values using the exchange rate and oil price, respectively, but positive correlation for both variables at the MA(3), MA(6), and MA(12) levels. Using time-series regression of the dependent variable and its MA values the same result was found as with the other Durbin-Watson statistical tests for India. However, none of the Q-statistical tests for the India dataset were found to be less than the 0.05 significance level. This indicates all of the other observed autocorrelations were white noise.

The relationship between exchange rates and stock prices was hypothesized to be positively related, showing that an appreciation (depreciation) of the domestic currency in terms of USD would have an unfavorable (favorable) impact on the domestic stock market. This relationship was found to exist between the stock index price and exchange rate for Brazil, Russia, and China. An interesting point in the results of the study was the relationship observed between respective stock market prices and monthly oil prices. As expected the relationship would be inverse, with an increase in oil prices having an unfavorable effect on stock market prices.

The analysis of the effect of international macroeconomic factors of exchange rate and oil price on the stock market exchange price of Brazil, Russia, India, and China did not reveal a significant relationship. This is based on the parameter values for the independent variables and their corresponding $p$-values of significance value and the $\mathrm{R}^{2}$ parameter for each model.

\section{SUMMARY AND CONCLUSIONS}

The analysis of the effect of international macroeconomic factors of exchange rate and oil price on the stock market exchange price of Brazil, Russia, India, and China did not reveal a significant relationship. This is not unexpected, as other international and domestic macroeconomic variables (e.g., production, inflation, dividend yield, interest rates, trade balance, rate structure) may also have a role in the determination of stock price expectations. Further research into the relationship between these other macroeconomic variables and stock prices is warranted. As the horizon of exchange rate and oil prices was extended by using their respective three- and six-month moving averages the $\mathrm{R}^{2}$ continued to decrease significantly.

As hypothesized, the relationship between exchange rates and stock prices should be positively related. This hypothesis was found to exist between the stock index price and exchange rate for Brazil, India, and China but not for Russia until the MA(12) level, which is possibly explained by the slight decreasing trend in the RBL/USD rate in the latter stages of 2003. With India in the infancy of its emerging economy, this relationship appears to not 
have had a chance to manifest itself as in the other countries already researched. Whereas for China, although it adheres to a fixed exchange rate regime, the exchange rate appears to have experienced dramatic increase at the MA(6) and MA(12) levels, more than likely due to the strong downward shift of about $0.270 \mathrm{CNY} / \mathrm{USD}$ after mid2005.

Another interesting point of the results is the relationship observed between respective stock market prices and monthly oil prices. As hypothesized, the relationship would be inverse. However this relationship was not consistent for all of the BRIC countries, which alternated between a positive or negative relationship as the timeframe was carried forward, with significance value only for India at MA(1). Since this study did not include other macroeconomic variables, such as inflation, it may be that oil prices themselves may not have as much of a profound effect as expected. Instead, the change in oil prices may be better reflected in the inflation rate, which may have a more profound effect on stock market prices. Also the exponential growth in oil prices did not occur until after the beginning of 2004, which is towards the end of the timeframe of this study.

The same alternation between positive or negative relationships was observed for the dependent variable and its moving average except for Russia at MA(1). It appears past stock market prices overall did not have a significant impact on current stock prices, as their respective regression parameters appeared to be considerably low in nature.

Although the explanatory values of both exchange rate, oil prices, and the lagged stock market prices were not significant, this study has shown the effect of other macroeconomic factors, both domestic and international, should also be explored for their relationship with stock market prices. Further research into this area may prove significant in explaining and possibly forecasting the direction of respective country stock market prices to both internal and external shocks.

Table 1 Summary of Results for Box-Jenkins MA(1)

\begin{tabular}{ccccc} 
Country/Coefficient & Brazil & Russia & India & China \\
\hline Constant & 1.91 & $8.35^{* *}$ & $1.78^{*}$ & 0.35 \\
MA(1) & -0.02 & -0.06 & $-0.44^{* * *}$ & 0.01 \\
Exchange Rate & $-16.03^{*}$ & 1.94 & -2.92 & -14.82 \\
Oil Price & 0.21 & 0.67 & $1.05^{*}$ & -0.06 \\
N & 88 & 88 & 88 & 88 \\
R-squared & 0.06 & 0.02 & 0.31 & 0.02 \\
Lyung-Box Q Significance & 0.784 & 0.427 & 0.670 & 0.938 \\
\hline
\end{tabular}

Table 2 Summary of Results for Box-Jenkins MA(3)

\begin{tabular}{ccccc} 
Country/Coefficient & Brazil & Russia & India & China \\
\hline Constant & 2.17 & $8.23^{*}$ & 1.93 & -0.12 \\
MA(1) & 0.05 & 0.01 & 0.28 & -0.09 \\
Exchange Rate & -15.54 & 4.81 & -5.41 & -14.81 \\
Oil Price & -0.36 & -0.18 & -0.12 & 0.52 \\
N & 87 & 87 & 87 & 87 \\
R-squared & 0.03 & 0.00 & 0.03 & 0.03 \\
Lyung-Box Q Significance & 0.698 & 0.409 & 0.023 & 0.877 \\
\hline
\end{tabular}


Table 3 Summary of Results for Box-Jenkins MA(6)

\begin{tabular}{ccccc} 
Country/Coefficient & Brazil & Russia & India & China \\
\hline Constant & 2.00 & $8.49^{*}$ & 1.58 & -0.51 \\
MA(1) & 0.01 & -0.02 & -0.09 & -0.12 \\
Exchange Rate & -23.86 & 5.71 & -3.13 & -82.10 \\
Oil Price & -0.02 & -0.60 & 0.00 & 0.40 \\
N & 84 & 84 & 0.00 & 84 \\
R-squared & 0.03 & 0.00 & 0.063 & 0.04 \\
Lyung-Box Q Significance & 0.502 & 0.457 & & 0.441 \\
\hline
\end{tabular}

Table 4

Summary of Results for Box-Jenkins MA(12)

\begin{tabular}{ccccc} 
Country/Coefficient & Brazil & Russia & India & China \\
\hline Constant & 1.59 & 5.65 & 2.87 & -0.50 \\
MA(1) & -0.01 & -0.06 & 0.11 & -0.08 \\
Exchange Rate & -49.91 & -1.10 & -18.92 & -152.70 \\
Oil Price & 0.49 & 5.56 & -1.82 & 0.51 \\
N & 78 & 78 & 78 & 78 \\
R-squared & 0.06 & 0.02 & 0.03 & 0.06 \\
Lyung-Box Q Significance & 0.447 & 0.419 & 0.044 & 0.592 \\
\hline
\end{tabular}

$* \mathrm{p}<.05, * * \mathrm{p}<.01, * * * \mathrm{p}<.001$

\section{REFERENCES}

1. Adrangi, B., Chatrath, A., \& Sanvicente, A. Z. (2002). Inflation, output, and stock prices: Evidence from Brazil. Journal of Applied Business Research, 18, 1, 61-76.

2. Abdullah, D. A. \& Hayworth, S. C. (1983). Macroeconometrics of stock price fluctuations. Quarterly Journal of Business and Economics, 32, 1, 49-63.

3. Akbar, Y. H. \& Samii, M. (2005). Emerging markets and international business: A research agenda. Thunderbird International Business Review, 47, 4, 389-396.

4. Anderlini, J. (2007). Chinese bourses eclipse all of Asia. Financial Times, May 10, 2007, 1.

5. Asia: Clipping the dragon's wings: Recalculating China's GDP. The Economist, December 22, 2007, 385, $8560,98$.

6. Basher, S. A. \& Sadorsky, P. (2006). Oil price risk and emerging stock markets. Global Finance Journal, $17,224-251$.

7. Burmeister, E. \& Wall, K. D. (1986). The arbitrage pricing theory and the macroeconomic factor measures. Financial Review, 21, 1-20.

8. Chen, N. F. (1991). Financial investment opportunities and the macroeconomy. Journal of Finance, 46, 529-554.

9. Chen, N. F., Roll, R., \& Ross, S. (1986). Economic forces and the stock market. Journal of Business, 59, 383-403.

10. DaCosta, M. M. N. \& Foo, J. P. N. (2002). China's financial system: Two decades of gradual reforms. Managerial Finance, 28, 10, 3-18.

11. Dallal, G. E., \& Wilkinson, L. (1986). An analytic approximation to the distribution of Lilliefor's test statistic for normality. The American Statistician, 40(4): 294-296.

12. DeFina, R. H. (1991). Does inflation depress the stock market? Business Review-Federal Reserve Bank of Philadelphia, Nov/Dec, 3-12.

13. Diacogiannis, G. P., Tsiritakis, E. D., \& Manolas, G. A. (2001). Macroeconomic factors and stock returns in a changing economic framework: The case of the Athens stock exchange. Managerial Finance, 27, 6, 23-41. 
14. Economic focus: Baby boom and bust. The Economist, May 13, 2006, Vol. 379, Iss. 8477; pg. 96.

15. Fama, E. F. (1970). Efficient capital markets: A review of theory and empirical work. Journal of Finance, 25, 383-417.

16. Fama, E. F. (1981). Stock returns, real activity, inflation and money. American Economic Review, 71, 545-565.

17. Fama, E. F. (1990). Stock returns, expected returns, and real activity. Journal of Finance, 45, 1089-1108.

18. Fama, E. F. (1991). Efficient capital markets: II. Journal of Finance, 46, 1575-1618.

19. Fama, E. F. \& Schwert, G. W. (1977). Asset returns and inflation. Journal of Financial Economics, 5, 115-146.

20. Fama, E. F. \& Gibbons, M. (1984). A comparison of inflation forecasts. Journal of Monetary Economics, 13, 327-348.

21. Fifield, S. G. M., Power, D. M., \& Sinclair, C.D. (2002). Emerging stock markets: A more realistic assessment of the gains from diversification. Applied Financial Economics, 12, 213-229.

22. Flannery, M. J. \& Protopapadakis, A. A. (2002). Macroeconomic factors do influence aggregate stock returns. The Review of Financial Studies, 15, 3, 751-782.

23. Fung, H. G. \& Lie, C.J. (1990). Stock market and economic activities: A causal analysis. Pacific-Basin Capital Markets Research, 203-214.

24. Gallagher, L. A. \& Taylor, M.P. (2002). Permanent and temporary components of stock prices: Evidence from assessing macroeconomic shocks. Southern Economic Journal, 69, 2, 345-362.

25. Geske, R. \& Roll, R. (1983). The fiscal and monetary linkage between stock returns and inflation. Journal of Finance, 38, 1-33.

26. Goodheart, C. M. L., \& Spicer, J. (2003). Monetary policy's effect during the financial crises in Brazil and Korea. International Journal of Finance and Economics, 8, 1, January 2003, 55-79.

27. Habibullah, M. S. \& Baharumshah, A.Z. (1996). Money, output, and stock prices in Malaysia: An application of the co-integration tests. International Economic Journal,_10, 2, Summer 1996, 121-130.

28. Hamao, Y. (1988). An empirical examination of the arbitrage pricing theory: Using Japanese data. Japan and the World Economy,_1, 45-61.

29. Huang, R. D. \& Kracaw, W.A. (1984). Stock market returns and real activity: A note. Journal of Finance, 39, 267-273.

30. Huang, X. (2004). China stock price reactions to financial announcements: Evidence from segmented markets. Managerial Finance, 30, 3, 62-73.

31. Huang, Y. (2006). The microeconomic rise of India. Far Eastern Economic Review, March, 169, $2,31-33$.

32. Ibrahim, M. H. (1999). Macroeconomic variables and stock prices in Malaysia: An empirical analysis. Asian Economic Journal,_13, 2, 219-231.

33. Ibrahim, M. H. \& Aziz, H. (2003). Macroeconomic variable and the Malaysian equity market: A view through rolling subsamples. Journal of Economic Studies, 30, 1, 6-27.

34. Jha, R. \& Nagarajan, H.K. (2000). The structure and price efficiency of an emerging market. International Journal of Commerce and Management, 10, 2, 50-59.

35. Kwon, C. S. \& Shin, T.S. (1999). Co-integration and causality between macroeconomic variables and stock market returns. Global Finance Journal,_10, 1, 71-81.

36. Kwon, C. S., Shin, T.S., \& Bacon, F.W. (1997). The effect of macroeconomic variables on stock market returns in developing markets. Multinational Business Review, Fall, 5, 2, 63-70.

37. Lee, U. (1997). Stock market and macroeconomic policies: new evidence from Pacific Basin countries. Multinational Finance Journal,_1, 4, 273-289.

38. Lilliefors, H. W. (1967). On the Kolmogorov-Smirnov tests for normality with mean and variance unknown. Journal of the American Statistical Association, 62, 399-402.

39. Ma, C. K. \& Kao, G. W. (1990). On exchange rate changes and stock price reactions. Journal of Business Finance and Accounting, 17(3), 441-449.

40. Maysami, R. C. \& Koh, T.S. (2000). A vector error correction model of the Singapore stock market. International Review of Economics and Finance, 9, 79-96.

41. Mookerjee, R. \& Yu, Q. (1997). Macroeconomic variables and stock prices in a small open economy: The case of Singapore. Pacific-Basin Finance Journal, 5, 377-388. 
42. Mudd, S., Grosse, R., \& Mathis, J. (2002). Dealing with financial crises in emerging markets. Thunderbird International Business Review, 44, 3, 399-430.

43. Mukherjee, T. K. \& Naka, A. (1995). Dynamic relations between macroeconomic variables and the Japanese stock market: an application of a vector error correction model. Journal of Financial Research, $18,2,223-237$.

44. Mukhopadhyay, D. \& Sarkar, N. (2003). Stock return and macroeconomic fundamentals in modelspecification framework: Evidence from Indian stock market. Indian Statistical Institute, Economic Research Unit, ERU 2003-05 Discussion Paper, January 2003, 1-28.

45. Muradoglu, G., Taskin, F., \& Bigan, I. (2000). Causality between stock returns and macroeconomic variables in emerging markets. Russian \& East European Finance and Trade, 36, 6, 33-53.

46. Nandakumar, P. \& Wague, C. (2004). A comparison of economic reforms and instability effects in three large emerging markets. The Journal of American Academy of Business, 4, 1/2, 198-204.

47. Nilsson, R. \& Brunet, O. (2005). Composite Leading Indicators for Major OECD Non-Member Economies: Brazil, China, India, Indonesia, Russian Federation, and South Africa. Organization for Economic Cooperation and Development, Statistical Directorate, OECD Statistics Working Paper, January 25, 2006.

48. Pagan, J. A. \& Soydemir, G. (2000). On the linkages between equity markets in Latin America. Applied Economics Letters, 7, 207-210.

49. Pearce, D. K. \& Roley, V.V. (1988). Firm characteristics, unanticipated inflation, and stock returns. Journal of Finance, 43, 965-981.

50. Pesonen, H. (1999). Assessing causal linkages between the emerging stock markets of Asia and Russia. Russian and East European Finance and Trade, 35, 2, 73-82.

51. Rocha, K. \& Garcia-Alcaraz, F.A. (2005). The term structure of sovereign spreads for emerging markets. The Journal of Fixed Income, 14, 4, 45-55.

52. Roll, R. (1977). A critique of the asset pricing theory's tests: Part I: On the past and potential testability of the theory. Journal of Financial Economics, March, 129-176.

53. Ross, S. A. (1976). The arbitrage theory of capital assets. Journal of Economic Theory, December, 341360.

54. Shapiro, S. S., and Wilk, M. B. (1965). An analysis of variance test for normality. Biometrika, 52:3, 591599.

55. Soenen, L. A. \& Hennigar, E. S. (1988). An analysis of exchange rates and stock prices-the U.S. experience between 1980 and 1986. Akron Business and Economic Review, 19(4), 7-16.

56. Solnik, B. (1987). Using financial prices to test exchange rate models: A note. Journal of Finance, 42(1), 141-149.

57. Tarzi, S. (2000). Hot money and emerging markets: Global political and economic determinants of portfolio capital flows. The Journal of Social, Political, and Economic Studies, 25, 1, $27-49$.

58. Tarzi, S. (2005). Foreign direct investment flows into developing countries: Impact of location and government policy. The Journal of Social, Political, and Economic Studies, 30, 4, 497-515.

59. Toloui, R. (2007). Petrodollars, Asset Prices, and the Global Financial System. PIMCO Bonds.

60. Tsoukalas, D. (2003). Macroeconomic factors and stock prices in the emerging Cypriot equity market. Managerial Finance, 29, 4, 87-92.

61. Wei, K.C., Wong, J., \& Matthew, K. (1992). Tests of inflation and industry portfolio stock returns. Journal of Economics and Business, 44, 77-94.

62. Wilson, D. \& Purushothaman, R. (2003). Dreaming with BRICs: The path to 2050. Goldman Sachs Global Economics Paper, 99, 1-22.

63. Wongbanpo, P. \& Sharma, S. C. (2002). Stock market and macroeconomic fundamental dynamic interactions: ASEAN-5 countries. Journal of Asian Economics, 13, 27-51.

64. Woodall, P. The new titans: A survey of the world economy. The Economist, September 16, 2006, 380, 8495, 4 . 